\title{
UN SANCTIONS AGAINST THE FRY: SOME MORAL ASPECTS OF A COERCIVE DIPLOMACY FORM*
}

This paper deals with UN economic sanctions against the FRY as the first in a series of forms of international intervention in the ex-Yugoslav crisis. In the first section, the author presents statistic indicators of the effects of sanctions on all subsystems of the Serbian society, corroborating the viewpoint that they were not more humane, but only, as it was observed by analysts, less noisy and less expensive means of coercion than application of armaments. In the following part of the paper the author concentrates on ethical aspects of this diplomatic instrument pointing out that it represents a form of collective punishment and as such being incompatible to the ethical principle of individual responsibility, i.e. attributability of responsibility to an individual for his own behaviour. As such they were not, as it was contended, an instrument of establishment of, by the acts of the incriminated regime disrupted international justice, but a punishment lever, which, as the author concludes, by its inadequacy (in respect of the choice of the target group to which the punishment was directed, differentiation of application, appropriateness to the committed act,...) took on the form of retaliation put into effect for the purpose of producing the desired state of affairs on the terrain of political interests instead of the declared international ethics "terrain".

Key words: UN sanctions, Yugoslavia, international politics, international ethics

"A nation that is boycotted is a nation that is in sight of surrender. Apply this economic, peaceful, silent, deadly remedy and there will be no need for force. It is a terrible remedy. It does not cost a life outside the nation boycotted, but it brings a pressure upon the nation which, in my judgment, no modern nation could resist."'

Winston Churchill

*Ovaj rad je realizovan u okviru projekta „Istraživanje klimatskih promena na životnu sredinu: praćenje uticaja, adaptacija i ublažavanje“ (43007), koji finansira Ministarstvo za prosvetu i nauku Republike Srbije u okviru programa Integrisanih i interdisciplinarnih istraživanja za period 20112014. godine.

${ }^{1}$ Quoted in: Hufbauer, Clyde, and Elliot, (eds.), 1990: 9. 
The UN economic sanctions against FR Yugoslavia ${ }^{2}$ were, chronologically taken, the first in the sequence of forms of international intervention in exYugoslav crisis. As such, they were an expression of continuity in practising of coercive diplomacy resorted to with lower or higher intensity since the foundation of the League of Nations until now. However, with the exception of the punitive measures against Iraq, introduced in August 1990, the sanctions against FR Yugoslavia, by numerousness and far-reaching effects of their punitive consequences, exceeded everything demonstrated till then in the diplomatic history of the world. Introduced on May 31, 1992 by the Resolution of the Security Council 757 , the sanctions were subsequently twice additionally intensified. The first time it was done in November the same year by the Resolution 787 of this UN body, and then in April 1993 by its Resolution 792, after which the Bosnian Serbs refused to sign the Vance-Owen plan, although Serbia and Montenegro supported this act and tried to persuade their compatriots from Bosnia to accept it. ${ }^{3}$ Neither after signing the Dayton Peace Agreement which ended the war in this former Yugoslav republic the sanctions were not cancelled but extended, i.e. the "external wall" of sanctions was introduced, although it was not specified by the Agreement or the resolutions of Security Council and European Union. The decision on its introduction was brought by USA, but it shortly became the international obligation. The list of the conditions for their suspension was extended as compared to those originally set up and it included the cooperation with the Hague Tribunal, settlement of Kosovo problem, establishment of good neighbourly relation with the countries created due to the disintegration of SFRY and general democratisation of the society. "Once they seize a powerful weapon such as sanctions, dominating countries strive to make maximal use of them, not only for realisation of the originally set goals, but also for other goals and conditions that they can subsequently remember", Kosta Mihailovic noted (1994: 3).

2 In the legal theory, sanctions include both the means influencing the adherence to social norm (sanctions in wider sense) and the means applied in case of disregard of the norm (sanctions in narrower terms). When its meaning is not specified, the term 'sanction' is used in narrower sense. In general usage in the Latin language the notion of sanction implied sanctity, announcement of sanctity, sanctification, consecration, solemn confirmation (thence its present usage as the synonym for confirmation), inviolability. In this article the term "sanction" will, clearly, be use in its narrower, nonspecified sense.

${ }^{3}$ See more about it in Lopez \& Cortright, 1995, also in Delevic, 1998.

${ }^{4}$ About which foreign policy goals the countries-initiators of the sanctions tried to achieve by their application see Hufbauer, Schott \& Eliot (eds.), 1983. 
Otherwise, even when they did not succeed in imposing sanctions as international, i.e. multilateral obligation, USA did not give up imposing the sanctions as an instrument of accomplishment their foreign policy goals. From 1993 to 1996 America introduced unilateral sanctions in relation to 25 countries. These countries are populated by 2.3 billion inhabitants altogether, i.e. 42 percent of the world population, having the market with the trade amounting to 790 billion dollars annually, which makes 19 percent of the total world market of goods and services. ${ }^{5}$ Thus the unilateral sanctions of USA against Cuba, introduced in 1961, are still in force, as well as those against Libya, introduced in 1992. "Lifting of sanctions is an act which represents voluntarism brought to the culmination, it is reached via a path which is often inconceivable; as if in some huge oblivion, certain societies remain for decades in the iron circle of sanctions", remarks Miroslav Pecujlic (1998: 165). The reason for which the sanctions imposed to Libya are not strictly applied lies only in the economic interest of Western countries, above all Italy and France, i.e. in their power dependence on supplies of Libyan oil. France is also persistently asking for alleviation of the sanctions against Iraq, having in mind large Iraqi debt to France and interest in further investment in Iraqi sources of oil. On account of economic interdependence of states, the application of economic sanctions, obviously also affects their initiators to a lesser, the same, or even to a greater extent. For these reasons, states do not want to, in this kind of punisher interrelations, place their power fully at the disposal of international organisations. ${ }^{6}$ In the period from 1945 to 1990 , sanctions as an instrument of coercive diplomacy on the international level were applied 104 times. USA had key role in two thirds of such cases.

As to the sanctions against FRY, the main reason for their introduction in May 1992, since the military engagement of FR Yugoslavia in the warfare in Bosnia and Herzegovina could not be proved, was recognised, according to an official of the European Community, not only in what Serbia and Montenegro do, but what they do not do. As Kosta Mihailovic specified, it implied that Yugoslavia "fails to use, allegedly great influence on the Serbs in Bosnia to stop armed struggle"

5 Cf. Unilateral Economic Sanctions, The President's Export Council, June 1997, quoted according to Teokarevic \& Mijalkovic, 1998: 61.

${ }^{6}$ The practice showed that the consistent application of sanctions against the target state was mostly ignored by economically most developed countries, as well as small countries vitally directed to cooperation with the state against which they were supposed to apply the sanctions. Therefore, it was in international relations much easier to achieve agreement on political condemnation, military and other steps which cost nothing or very little the states that use them. Interests, in this case economic ones, therefore, mostly referred to preponderance over the professed international moral motives for resorting to this form of coercive diplomatic measures. For more see Milojevic, 1994: 28. 
(1994: 4). ${ }^{7}$ Although by the same Resolution which announced the introduction of sanctions against FRY, the Security Council also concluded the presence of "elements" of the Croatian army in this ex-Yugoslav republic affected by the brutal interethnic war, no form of economic punishment has ever been introduced against the state of Croatia on account of its war participation in the Western Balkans" "Yugoslavia in microcosm". "Therefore, the question is not about what was done, but about who committed a punishable act, which party in the conflict has powerful protection, i.e. suzerainty of a great power, and which is deprived of them", Miroslav Pečujlic concludes (1998: 165).

Either in many cases more drastic than the Croatian case, the international community, i.e. its most influential members did not use sanctions as punishing diplomatic instrument. For example, during the Indonesian invasion of East Timor in the period from 1975 to 1979 over 200 thousand people were killed, which was one third of the population of the invaded state. None of the members of the international community condemned that massacre, nor the United Nations by any resolution called the leaders of Indonesia to account. The Resolution of the UN General Assembly from 1982 requesting the achievement of a comprehensive agreement was not accepted, because 45 countries including USA which as well as Australia supplied the Suharto's regime with armaments, voted against. In spit of the occupation of East Timor, Western countries in the period from 1987 to 1989 through donations and credits granted to Indonesia a sum over 10 billion dollars. In September 1999, after disclosing the findings on intensifying the violence of the Indonesian regime against the secession-oriented population, the Clinton administration reacted by repeating the position that "East Timor is the responsibility of the Government of Indonesia and we don't want to take that responsibility away from them" $"$ This long line of indifference, or even support to these gross

${ }^{7}$ The overseas perception of the then condition in the Western Balkans regions and its ensuing motives for American initiatives in the United Nations resulting in introduction of the sanctions against FRY had, however, a considerably different formulation. Namely, in the presidential statement that George Bush, president of USA at that time, signed on 30 May 1992, one day before voting for the respective resolution of the Security Council, it is said "that the actions and policy of the governments of Serbia and Montenegro, acting under the name of Socialist Federal Republic of Yugoslavia, by their intervention and support to the groups that strive to seize the territories in Croatia and Bosnia and Herzegovina by force and violence, using partly the forces of the so called Yugoslav National Army, make an uncommon and exceptional threat to the national security, foreign policy and economy of USA." Cf. Presidential Document, Executive Order 12808 dated May 28, 1992. Blockade of the Property of the Yugoslav Government and properties of the Governments of Serbia and Montenegro, quoted according to Bulajic, 1994: 57, italic M.R.

${ }^{8}$ Quoted according to Chomski, 2004: 54. 
violators of the provisions of the international law, is explained, as Radmila Nakarada reminds, by the information disclosed a few years later that the presidential campaign of Bill Clinton, among other things, was also financed by the money of Indonesian businessmen. ${ }^{9}$

As to the events in the regions of ex-Yugoslavia, the international community, primarily USA as its most powerful member, rhetorically speaking, demonstrated considerably more humanitarian sensibility and readiness for punishment of the objectionable regime. On the level of declaratory, officially proclaimed goals, the sanctions were less violent, less inhuman tool of international political intervention in the war on the territory of Bosnia and Herzegovina, i.e. the instrument of coercing the Serbian regime to contribute by its acts to the termination of war conflicts and establishment of peace in this former Yugoslav republic. As such, they were supposed, as suggested by some analysts ${ }^{10}$, to issue a new, higher price to the target government for continuing with the behaviour which by introduction of the sanctions was estimated as unacceptable.

The monotonous but relentless language of figures most eloquently testifies about the amount of that price, i.e. to which extent the sanctions were truly "less inhuman" tool of the international political intervention in the events in the regions of war affected Western Balkans.

\section{1) Blockade in the Mirror of Statistics}

According to the official statistical data, the industrial production in FRY in 1993 fell to the level of 25 percent of the production in 1989, while the gross national income per capita was decreasing at the rate of 10-25 percent annually

${ }^{9}$ Cf. Nakarada, 1998: 99. Neither the apartheid regime in South Africa for long thirty years could be deposed by the international community. Introduced in stages from the beginning of the seventies till the mid-eighties, the sanctions against it were never rigorously applied. Their economic punishing measures were directly boycotted by the western countries, while at the time when the armaments import embargo to South Africa was still in effect, USA was secretly supporting in its combat against the countries of the "first line" and in defence of apartheid. In addition, in 1982 they arranged from the international monetary fund a loan for South Africa amounting to one billion dollars. "The struggle of the African National Congress, the internal resistance, the fact that the surrounding countries gained independence (for example, Rhodesia, now Zimbabwe) contributed more to abolishment of apartheid than the pressure of the international condemnation and application of sanctions. In other words, the international community relied on the internal course and outcome, instead of using the available instruments consistently and efficiently to prevent creation and survival of the racist regime." (Nakarada, 1998: 100)

${ }^{10} C f$. Kerr, W. A. \& Gaisford, J. B. (1994). A Note on Increasing the Effectiveness of Sanctions. Journal of Word Trade 28 (6): 170 (quoted in Prokopijevic, 1998: 13). 
and in 1993 it amounted to only 40 percent of the income in 1989 (910 American dollars). This was an effect considerably lesser than the one produced by the sanctions against Iraq, but also considerably greater than the effect of any other sanctions in history, which never exceeded the figure of 16 percent gross national income. ${ }^{11}$ The external debt reached the level of about 9 billion dollars, while the unemployment rate increased to 25-30 percentage points, not counting about 800 thousand workers on compulsory vacation, which in 1993 made about 40 percent of active labour force. The average income in the second half year in 1993 fell to 20 dollars, and the hyperinflation of the official state currency with monthly rise from 50 percent to over 100 percent (in December 1993, 200,000 percentage points surpassing the earlier record of the Weimar Republic) caused complete collapse of the banking system and regression to primitive forms of natural exchange, i.e. degradation of the long ago reached level of culture of financial operation.

General scarcity, hyperinflation and market blockade created suitable ground for development of grey economy, which, while devaluating the ethos of work as the only socially tolerable manner of acquisition of wealth, by elementary force penetrated in all fields of economy, reaching the maximum expansion in the commercial sphere and the sphere of pecuniary transactions. In 1992 this illegal form of economic operation, had within the total value of registered gross national product a share amounting to 42 percentage points, and in the aggregate (registered and unregistered) gross national product of FRY a share above 29 percent. On the social level it caused enormous property redistribution among the population, i.e. drastic stratification and social-group antagonizing of the small class of nouveaux riches close to the condemned regime (about 5 percent) on one side, and an immense mass pauperised population (about 95 percent), on the other, which seriously jeopardised the social and psychological conditions for establishment of the social consensus necessary for large-scale and painful social changes faced at that time by the Serbian society. ${ }^{12}$

The lack of resources, chiefly material ones, was compensated by consumption of human resources. On the individual level, on the level of everyday life the "sanctions produced (...) special strategies of survival, mostly based on grey economy and devastation of human resources, primarily women resources, through domestic work and rendering care to household members. Exhausting of the woman's energy, health and time made up for what was lacking and what was necessary for subsistence" (Blagojevic, 1994: 150).

For a very short time, from the society with relatively high degree of personal and property security, Serbia became a society with particularly high degree of

${ }^{12}$ See more in Cobeljic, 1994, and Sekelj, 1998. 
property and personal insecurity. A sociological research carried out on the territory of Belgrade in April 1994 showed that as many as 10 percent of respondents had been victims of crime in the previous several years, as many as 15 percent of them acquire weapons, and as many as 43 percent feel fear and insecurity because of the proportions of criminalisation of the society. ${ }^{13}$

The abrupt reduction of the possibility of business trips abroad increased migration intentions and stimulated the outflow of highly qualified manpower, i.e. human capital (brain drain), which caused serious problems in functioning of vital social institutions (health-related, educational, scientific...), but also drastically reduced social potentials for the imminent changes, whose protagonists in every society are young, educated and initiatory individuals. Therefore, during 1992 the country was abandoned by 200, and in 1993 another 170 scientific researchers. In addition, those who went abroad included mostly young researchers in the field of physics, mathematics, electronics and chemistry, out of which about 60 percent were younger than 40 and about 40 percent of them acquired the academic titles of doctor and master of arts in this country. The amount of loss incurred related to their schooling is sufficiently indicated by the data showing that the state earmarked 50-100 thousand dollars for each of them for these purposes. In the period from 1991 till 1993 only one Serbian scientific institution (the Institute "Mihajlo Pupin") was abandoned by so many researchers that they could have easily formed an institute outside the country, "probably even better than this one here" (V. Grecic).

The sanctions also accelerated an intense demographic decline of population, i.e. a severe fall of birth-rate and similar increase of death rate. The volume of natural population growth rate which in early eighties amounted to about 25,000 persons was quickly decreasing, so that in 1992 and 1993 the number of the deceased surpassed the number of the live-born by several hundreds of persons. "A demographic period started that was, in absence of active policy, anticipated and expected, but not so abrupt and not so soon", concluded Milos Macura (1994: 130).

The effects of economic blockade countries had also striking repercussions on the quality of medical services, severely jeopardising the physical and mental health of the punished population. Thus, in the first years of sanctions, there were in the cardiologic section of a Belgrade children hospital, at least 250-300 children with congenital, but operable heart defects, annually remaining unoperated due to material reasons caused by the effect of the sanctions. The implications of this sit-

${ }^{13}$ Cf. Survey on New Phenomena in Everyday Life of Serbia, Institute for Sociological Investigations (ISI) of the Faculty of Philosophy in Belgrade. 
uation were fatal for them - they would rapidly pass into surgically high risk group, becoming thereafter inoperable and died in the end. The overall health condition of children, according to a number of parameters worsened by 10 percent, with the deterioration rate of 4 percent annually. In two years of the sanctions (1991-1993) the total death rate of children increased by 63 percent.

In the medical annals of former Yugoslavia, the period of sanctions will remain recorded as the time of large-scale famine, malnutrition and occurrence of the long ago eradicated diseases. Thus in the period from 1989 to 1993, the share of newly discovered and relapse tuberculosis patients in the total number of hospitalised patients, increased from 0.60 (1989) to 1.34 percent (1993), while the number of infectious diseases on the whole in that period increased by 141 percentage point. The average age affected by infarction of myocardium fell from 61 to 57 years of age, the death rate in persons older than 65 increased by 13 percent, the number of incorrect clinical diagnoses found in the Institute for Pathology of the Faculty of Medicine in Belgrade, rose from 25 percent (1989) to 31 percent (1993), ... The manager of a specialised psychiatric institution in Belgrade reported that by the end of 1993 "helpless, experienced, highly qualified physicians could only sit by their frozen patients, hungry and tied up, with mange and lice" (Kanjuh, 1994: 157 et passim).

If such a high social price of economic sanctions is taken into account, as Jovan Teokarevic and Aleksandra Mijalkovic point out, "there is a lot of basis for an assertion that the sanctions as a 'peaceful alternative to a military intervention' are essentially not more humane instrument than the use of weapons, being just less noisy and less expensive" (1998: 176). Moreover, as Hans Köchler noticed, it turns out that the higher standards of humanitarianism are applied to the war itself "than to so-called non-military coercive measures which, like war, can lead to death and mass deprivation" (Köchler, 1995: 132).

\section{2) Sanctions - Instrument of Retaliation or Establishment of Peace?}

The regimen of thus designed sanctions had, as we have established, as their declaratory goal, to provoke certain political acts of the targeted regime, i.e. its coercion to comply with political requests of the initiators of the sanctions. The instrument for realisation of this goal was inflicting pain to the population, from which it was expected to cause the desired state of affairs - the target compliance of the respective regime. Actually, "the power to hurt is bargaing power. The exploit it is diplomacy vicious diplomacy, but diplomacy"( Schelling , 2008:2). The elements of such collective injury were: collective isolation, economic and not only economic deprivation and, as a collateral effect, social devaluation (ill repute of the target group or people). "Each of these methods is aiming at jeopardising some of the basic human needs 
(physical survival, need for security and belonging, for self-respect, etc.) after which, supposedly (according to the logic of the Papin's pot effect), follows general social discontent, reducing of the degree of support to the elite in power and its policy and strengthening of social and political pressure (or even formation of social and political movements) with the purpose to realisation of greater influence on making political decisions, change of the current policy, or even deposing the ruling political group" (Vasovic, 1998: 143).

The measures of coercion such as the economic sanctions against FRY are therefore a form of collective punishment and as such they are incompatible to the ethical principle of individual responsibility, i.e. attributability of responsibility to an individual for his own behaviour. The punishment of the citizens who are not responsible for political decisions of their elites, categorical are McMahan and Kim, is the most similar to terrorist measures; the purpose of these measures is to influence the direction of actions of a certain regime by planned jeopardising of civil population (McMahan \& Kim, 1993: 536). The target punishment of the innocent is, however, amoral act per se, one of those that cannot be justified by any argumentative construction of the utilitarian ethics, the ethics of good intentions which ultimately maximizes the welfare of a group. Even if the individuals subjected to certain coercion measures are the victims of good intentions of addressees of such measures and not of their devised target endeavour to inflict suffering to the former, the effect of these measures on their recipients is identical. Nevertheless, in case of economic sanctions as coercion measures, this difference (between good intentions and their bad and unwanted effects) which the so-called "doctrine of double effect"14 is trying to articulate on the utilitarian ethics trail is not of any significance because it is simply non-establishable. Privations and suffering of the civil population subjected to economic sanctions are not, actually, their secondary and accidental, but their central and intended effects. The sanctions are therefore much more similar to that which Quinn calls terrorist bombing than to strategic bombing. In case of the latter, the possibility of the civil population being subjected to suffering is simply tolerated; in case of the former, it is maximally and deliberately exploited with the purpose of coercion of the regime to change the course of action. The comprehensive economic sanctions as imposed to Serbia and Montenegro therefore have the ethical quality of terrorist bombing: the civil population is, from the viewpoint of "security" strategy of the traditional policy of power of the key protagonist of the today's international relations, explicitly treated as hostage in its own country. It is self-evident, concludes Köchler, that this manner of political instrumentalisation of human being - as a citizen of a certain state which is a subject of international law - is not compatible to his status of an

${ }^{14}$ More about it in Quinn, 1989: 334-351. 
autonomous subject and to human dignity respectively. People have natural right not to be sacrificed to strategic goals on whose formulation and realisation they have no practical influence. As Quinn says "they have a right not to be pressed, in apparent violation of their prior rights, into the service of other people's purposes" (Quinn, 1989: 350). In the domain of ethics, the so-called "doctrine of double effect" provides every individual to the "veto right' "to a certain kind of attempt to make the world a better place at his expense" (ibid, 351). This right attacks upon a purely utilitarian approach (maximization of utility) which, in case of sanctions, can require sacrifice of health and prosperity of a whole people to foreign policy goals of the member states of the Security Council or another coalition of states, ready to resort to them at a specific moment as an instrument of coercion. Actually, "one cannot intentionally cripple an economy without intentionally affecting the people whose working and consuming lifes are partially constitutive of that economy" (McMahan \& Kim, 1993: 540). And beings whose existence, "indeed, is not based on our will, but on nature, still have, if they are beings without mind, only some relative value, as instruments, and therefore they are called things, while on the contrary, intelligent beings are called persons, because their nature itself differentiates them by distinguishing them as purposes by themselves, i.e. as something that must not be used only as an instrument, and to that extent puts limits on every self-will (and represents a subject of respect)" (Kant, 1981: 73).

In relation to sanctions, "the use of military intervention has an advantage, being a lesser instrument of collective retaliation, and more in the function of influence upon the political elite, or at the worst, in the function of punishment of those having actual influence upon making political decisions" (Vasovic, 1998: 151). In order to be morally acceptable, economic sanctions should be, as David Cortright (1999) cautions, as to their effects, immensely different from armed means of coercion, the sanctions being presented by their initiators as a less destructive alternative. Such as they are, sanctions are, it turns out, "a tool which actually a form, of violence - nothing lesser than guns and bombs - and it is an ethical imperative to see them as such" (Joy, 1999: 150). In other words, to advocate sanctions as an instrument of diplomacy means to advocate a "radically indiscriminate act of war with predictably harsh consequences" (Walzer, 1992: 3). Because, a siege (which economic sanctions in ultima ratio are) is, ultimately, a war act, tactically rational "as it guarantees maximum profit from minimum investment: if you want to destroy someone, without investing much, particularly if you do not want to have it directly seen, nor you want to assume the responsibility for it (which would in some open occupation nevertheless have to be done in some way) then it is best to destroy him from inside, and closing seems to be even essential condition for such a goal" (Babic, 1998: 198). War is actually, explains Babic, as a form of human practice and as a social phenomenon, 
defined through suspension of a significant part of positive laws, both those applicable to the relations toward the outside, and those regulating intrastate relations. Resorting to an instrument of coercive diplomacy with equivalent effects, the beneficiaries of the New/Old World Order, believes Hans Köchler, treat the provisions of the UN Charter referring to collective security as narrow passages to the old policy of power, while justifying medieval methods of siege - and war tactics which include introduction of total blockade of the state which in economic sense is not self-sufficient $^{15}$ - as measures of protection of peace and human rights. Article 41 of the United Nations Charter actually approves the use of economic and other non-military measures for maintenance or establishment of international peace and security, not using the term 'sanctions' for their designation. The Charter, reminds Köchler, assigns to the Security Council the monopoly about the definitions in this domain; it decides at its discretion whether it is a threat to peace, termination of peace or an act of aggression in action. Favouring these motives for imposing economic measures of enforcement rather than the principles of protection and promotion of human rights, which the Charter in its other documents refers to ${ }^{16}$, the Charter remains a "classical" instrument of the old policy of power in the hands of the protagonists of the socalled New World Order. And human rights, taken in social-economic terms, therefore, as the rights referring to the individual rather than to the collective legal person, as Köchler cautions in another place, "must be regarded as a general normative system from which the normative systems of both national and international law are derived (and not vice-versa)" (Köchler, 1995a: 72). ${ }^{17}$ These fundamental human rights which also include the basic economic and social rights are, as Köchler points out, the precondition of validity of fundamental rights and freedoms in classical Euro-

${ }^{15}$ Specific economic conditions in the country-object of sanctions are, along with their scope (partial or comprehensive), factors of decisive effect on their moral evaluation. In economically less autarkic or more dependent states, their effect on the conditions of life of the target population is much greater, and therefore the ethical implications of their application are much more serious.

16 The paragraph 1 of the First article of the Declaration on the Right to Development, adopted by the Resolution of the UN General Assembly (XLI) of December 4, 1986 says that the Declaration establishes inalienable human individual and collective right to development. This right is directed against coercive economic measures which, as the practice proves, often lead to massive human privation and suffering. According to this article: "The right to development is inalienable human right by virtue of which every human person and all peoples are entitled to participate in, contribute to and enjoy economic, social, cultural and political development, in which all other human rights and fundamental freedoms can be fully realised." Quoted according to Köchler, 1995a: 146.

${ }^{17}$ Among the human rights, Köchler reminds, there is a particular hierarchical order. Within this order, the right to life is of primary significance. The international or the world peace is, as pointed out by this author, in the documents of the United Nations defined for the viewpoint of thus graded human rights. 
pean sense (civil and political rights). Therefore the former ones cannot be sacrificed in the name of the latter, because, the intelligent nature, as formerly cautioned by Immanuel Kant, exists as a purpose by itself. "Thus a man necessarily conceives his own existence; therefore, it is a subjective principle of human actions. But, similarly any other intelligent being conceives his existence according to exactly the same intelligent basis which also applies to me; therefore, this is at the same time an objective principle which should serve as the highest basis for deriving all the laws of will. Accordingly, the practical imperative will be: Act in the way so that you always use humanness in your personality, as well as in the personality of any other man simultaneously as a purpose, and never as a tool only" (Kant, 1981: 74) In other words, when a man, instead of a goal, becomes a tool for maximisation of good, such as it is at least declaratively conceived by a certain group of the protagonists, "morality falls out of the picture, and then it is the non-moral ideal being in action" (Kymlicka, 1999: 34).

Treating their addressees as tools, and not as goals of their "good" effects, the sanctions against FRY were not, as contended, an instrument of establishment of the international justice disrupted by the acts of the incriminated regime, but a punishment lever, which by its inadequacy (in respect of the choice of the target group to which the punishment was directed, differentiation of application, appropriateness to the committed act,...) took on the form of retaliation put into effect for the purpose of producing the desired state of affairs on the political-interested, instead of the declared international-ethical "terrain". As such, they did not only mean goodbye to reason (E. Jeremic), but also a goodbye to the announced international morality.

\section{LITERATURA}

Babic, Jovan (1998). Sanctions - An Ethical Analysis. In: M. Prokopijevic and J. Teokarevic (eds.), Economic Sanctions of UN: Comparative Analysis and the Case of Yugoslavia, Belgrade: IES, pp. 191-202.

Blagojevic, M. (1994). Sociological Aspects of Sanctions. In: Sanctions: Causes, Legitimacy, Legality and Consequences, Belgrade: SANU, pp. 147-157.

Bulajic, M. (1994). Illegality and Baselessness of the Sanctions of the UN Security Council against FR Yugoslavia and System of Contemporary International Relations. In: Sanctions: Causes, Legitimacy, Legality and Consequences, Belgrade: SANU, pp. 51-65.

Chomski, N. (2004). Hegemony or Survival: America's Quest for Global Dominance. London: Penguin Books.

Cobeljic, N. (1994). Extraordinary Conditions of Business Operation Require Extraordinary Economic and Political Measures. In: Economy of Yugoslavia in Conditions of Blockade, Belgrade: Serbian Academy of Sciences and Arts, pp. 15-25.

Cortright, D. (1999). Humanitarian Sanctions? The Moral and Political Issues. $<$ http://www.wcl.american.edu/hrbrief/v3i1/cortri31.htm $>26.2 .2011$. 
Delevic, M. (1998). Economic Sanctions as a Foreign Policy Tool: The Case of Yugoslavia. The International Journal of Peace Studies 1(3) <http://www.gmin.edu/programs/ icar/ijps/vol.3 1/cover3 1.htm> 29.4.2011.

Hufbauer, G.C., Schott, J. J., Eliot, K. A. (eds.) (1983). Economic Sanctions in Support of Foreign Policy Goals. Washington, D.C.: Institute for International Economics.

Hufbauer, G., a.o. (eds.) (1990). Economic Sanctions Reconsidered: Supplemental Case Histories. Washington: Institute of International Economics.

Joy, G. (1999). Reply to George A. Lopez's 'More Ethical than Not'. Ethics and International Affairs 13: 149-150.

Kant, I. (1981). Zasnivanje metafizike morala (Foundations of Metaphysics of Moral). Beograd: BIGZ.

Kanjuh, V. (1994). Effects of Sanctions on Health of Population. In: Sanctions: Causes, Legitimacy, Legality and Consequences, Belgrade: SANU, pp. 157-171.

Kerr, W. A. \& Gaisford, J. B. (1994). A Note on Increasing the Effectiveness of Sanctions. Journal of Word Trade 6 (28): 162-178.

Köchler, Hans (1995). The United Nations Sanctions Policy and International Law. In: H. Köchler, Democracy and the International Rule of Law. Propositions for an Alternative World Order, Vienna and New York: Springer, pp. 117-154.

Köchler, Hans (1995a). Democracy and the International Rule of Law. Vienna and New York: Springer.

Kymlicka, Will (1990). Contemporary Political Philosophy. London: Clarendon Press.

Lopez, G. A. \& Cortright, D. (1995). Economic Sanctions in Contemporary Global Relations. In: G. A. Lopez \& D. Cortright (eds.), Economic Sanctions: Panacea or Peacebuilding in a Post-Cold War World, Boulder: Westview Press, pp. 3-16.

Macura, M. (1994). Demographic Implications of Secession and Economic Blockades. In: Sanctions, Causes, Legitimacy, Legality and Consequences, Belgrade: SANU, pp. 109135.

McMahan, J. \& Kim, R. (1993). The Just War and the Gulf War. In: Canadian Journal of Philosophy XXIII (4): 506-518.

Mihailovic, K. (1994). Sanctions - Punishment for Committed Act or Means of Political Pressure. In: Sanctions: Causes, Legitimacy, Legality and Consequences, Belgrade: SANU, pp. 9-15.

Milojevic, M. (1994). International Sanctions. In: Sanctions: Causes, Legitimacy, Legality and Consequences, Belgrade: SANU, pp. 15-39.

Nakarada, R. (1998). Sanctions - Between the Rule of Law and Domination. In: M. Prokopijevic and J. Teokarevic (eds.), Economic Sanctions of UN: Comparative Analysis and the Case of Yugoslavia, Belgrade: IES, pp. 97-106.

Pecujlic, M. (1998). Two Sides of Sanctions. In: M. Prokopijevic and J. Teokarevic (eds.), Economic Sanctions of UN: Comparative Analysis and the Case of Yugoslavia, Belgrade: IES, pp.164-168.

Quinn, W. (1989). Actions, Intentions and Consequences: The Doctrine of the Double Effect. Philosophy and Public Affairs XI: 334-351.

Schelling, T. C. (2008). Arms and Influence. New Haven and London: Yale University Press.

Sekelj, L. (1998). Effect of Sanctions of the Security Council. In: M. Prokopijevic and J. Teokarevic (eds.), Economic Sanctions of UN: Comparative Analysis and the Case of Yugoslavia, Belgrade: IES, pp. 153-163. 
Mirjana Radojičić, UN Sanctions Against the FRY: Some Moral Aspects of a Coercive...

Survey on New Phenomena in Everyday Life of Serbia, Institute for Sociological Investigations (ISI) of the Faculty of Philosophy in Belgrade.

Teokarevic, J. and Mijalkovic, A. (1998). UN Sanctions against FR Yugoslavia in Comparative Perspective. In: M. Prokopijevic and J. Teokarevic (eds.), Economic Sanctions of UN: Comparative Analysis and the Case of Yugoslavia, Belgrade: IES, pp. 51-85.

Vasovic, M. (1998). Justifiability of Sanctions, in: Prokopijevic. In: M. Prokopijevic and J. Teokarevic (eds.), Economic Sanctions of UN: Comparative Analysis and the Case of Yugoslavia, Belgrade: IES, pp. 141-152.

Walzer, Michael (1992). Justice and Injustice in Gulf War. In: D. De Cosse (ed.), But Was It Just? Reflections on the Morality of the Persian Gulf War, New York: Doubleday, pp. 117.

Мирјана Радојичић

Сажет̄ак

Универзитет у Београду

Институт за филозофију и друштвену теорију

\section{САНКЦИЈЕ ОУН ПРОТИВ СРЈ: НЕКИ МОРАЛНИ АСПЕКТИ јЕДНОГ ОБЛИКА ДИПЛОМАТИјЕ ПРИНУДЕ}

Предмей рада су економске санкције ОУН йройив СРЈ као ӣрва у низу форми међународної иниеервенисана у ех-јуїословенску кризу. У йрвом делу рада ауйорка

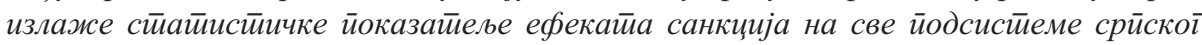

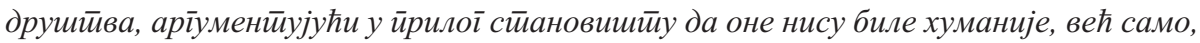
како су уочили аналитиччари, мање бучно и јефитиније средсииво йринуде од ирримене оружја. У следећем делу рада ауйорка се усредсређује на ейичке асйекйе овоі

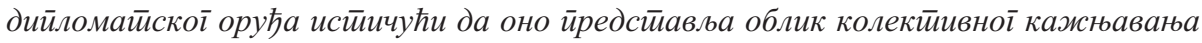
и да је као йакво инкомйайибилно етиичком йринцийу индивидуалне оді̄оворносиии,

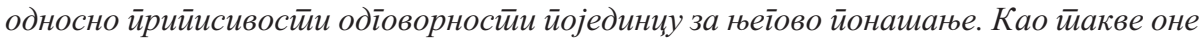

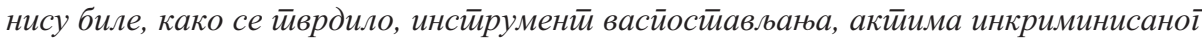
режима нарушене међународне йравде, већ йолуіа кажнавања, које је, закључује ауйока, својом неадеквайношћу (у йойледу избора циљне іруйе на коју је казна усмерена, диференцираносиии иримене, иримереносиии йочињеном делу,...) йоиримило форму одмазде, сиировођене у сврхе ирроизвођења жељеноі сииања сиивари на йоли-

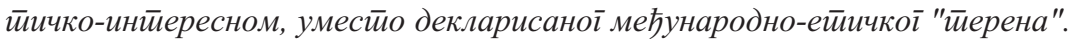

Кључне речи: санкције УН, Јуїославија, међународна йолийика, међународна ейика 